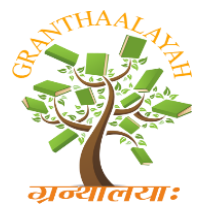

INTERNATIONAL JOURNAL OF RESEARCH GRANTHAALAYAH

A knowledge Repository

Science

\title{
STATURE ESTIMATION FROM PARTIAL MEASUREMENTS AND MAXIMUM LENGTH OF UPPER LIMB BONES IN KOREANS
}

\author{
Je-Hun Lee ${ }^{1}$, Young-Gil Jeong ${ }^{1}$, Nam Seob Lee ${ }^{1}$, Seung Yun Han ${ }^{1}$, Seung-Ho Han*2 \\ ${ }^{1}$ Department of Anatomy, College of Medicine, Konyang University of Korea, Daejeon, \\ KOREA \\ ${ }^{2}$ Department of Anatomy, College of Medicine, Chungang University of Korea, Seoul, KOREA
}

\begin{abstract}
The aim of this study was to develop regression equations for stature estimation using the upper limb bone in Korean individuals. A total of 105 samples (55 men and 50 women) obtained from cadavers were used for developing equations. Bones with obvious pathologies or healed fractures were excluded. The coefficient of determination ( $r 2)$ of the variables was slightly higher in men than in women. Ulna length $(M L U)$ in both sexes was found to have the highest $r 2$ value. Moreover, the regression equation using a stepwise analysis in a sample of combined sex using partial segments was based on MLR (Maximum length of the radius), MLH (Maximum length of the humerus) and TDHH (Transverse diameter of the humeral head) ( 2 $=0.949$ ). This method can be used to estimate stature when unidentified human bones are found at excavation sites.
\end{abstract}

Keywords:

stature estimation; upper limb bone; Korean.

Cite This Article: Je-Hun Lee, Young-Gil Jeong, Nam Seob Lee, Seung Yun Han, and Seung-Ho Han, "STATURE ESTIMATION FROM PARTIAL MEASUREMENTS AND MAXIMUM LENGTH OF UPPER LIMB BONES IN KOREANS" International Journal of Research - Granthaalayah, Vol. 3, No. 10(2015): 100-107. DOI:10.29121/granthaalayah.v3.i10.2015.2936

\section{INTRODUCTION}

Identification of an unknown body who died in mass disasters, wars, homicide, suicide or accidental deaths is a very important component of identification for forensic anthropology. Long bones are usually used to estimate stature (1), and a number of studies from various populations have reported regression equations for this estimation.

Since Telkka (2) in 1950 reported stature estimation using long bones in Finland, numerous reliable regression equations using long bones have been developed for various populations (316). All these studies were limited because they lacked well-documented recent skeletal material, in part because of secular trends in height (10). 
Shahar and Pooy (17) developed regression equations to estimate stature from arm span and knee height in Malaysian individuals. Kimura (18) estimated stature from the second metacarpal bone; other regression equations $(19,20)$ have been developed from limb bone length in Japanese individuals. A few regression equations were additionally developed for stature estimation from limb bone length for Chinese (21,22), Hong Kong (23), and Thai (24) populations.

Choi et al. (25) studied the correlation between postmortem stature and dried limb bones of only adult Korean men. Estimating stature from fragmented bone is difficult. Therefore, regression equations that allow stature estimation from partial measurements of the long bone are required.

Anthropometric dimensions vary with populations, even in subjects of the same continent, and these variations are attributed to genetic and environmental factors $(5,10,25)$. In a Korean study, regression equations for estimating stature using long bones have been developed, but only in male subjects (25). Moreover, differences in stature have been observed with secular changes (10). According to a recent study, a large increase in Korean stature was observed at the beginning of the 20th century (26). Therefore, in the present study, we created specific formulae or regression equations to predict stature of Korean individuals.

The aim of this study was to develop equations for estimating stature from upper limb bones, and to collect forensic and anthropological data with which stature can be estimated when partial bone remains are found.

\section{MATERIALS AND METHODS}

Height and lower limb bone lengths were measured for 105 adult Korean cadavers (55 men, 50 women) between 42 to 95 years of age (mean, 71.7 years; standard deviation, 14.0 years). Stature was measured after death from the inferior part of the heel to the vertex in the supine position. The long bones were removed from fresh cadavers. Articulate cartilage was removed using a surgical knife. No bones with obvious pathologies or healed fractures were included, and all measurements were taken using an osteometric table (Osteometric table, EGO, Korea) and digital calipers (Mitutoyo, Tokyo, Japan).

Seven variables were measured: maximum length of the humerus (MLH), vertical diameter of the humeral head (VDHH), transverse diameter of the humeral head (TDHH), maximum diameter of the humeral head $(\mathrm{MDHH})$, epicondylar breadth of the humerus $(\mathrm{EBH})$, maximum length of the ulna (MLU), and maximum length of the radius (MLR) (Table 1).

Statistical analysis was performed using SPSS 17.0 (SPSS Inc., Chicago, IL) for Windows. Means and standard deviations of the results of individual factors were calculated and statistically analyzed to identify any significant differences.

\section{RESULTS}

There was no statistically significant difference between right and left limb bone length (paired ttest; $\mathrm{P}>0.05$ ). Regression analysis was therefore performed with right bones only. Because there 
was a statistically significant difference between men and women, the regression equations were made independently for each sex $(\mathrm{P}<0.05)$.

Table 2 presents the means and standard deviations of all variables for both sexes. The mean values of all measurements used in the present study were significantly higher in men than in women.

Table 3 presents the resulting regression equations for stature estimation in male subjects. In men, MLU was found to be the most appropriate variable for stature estimation $(\mathrm{r} 2=0.899)$. In the equation derived from stepwise regression analysis using partial segments, 3 variables-MLU, MLH and TDHH - were selected for male subjects (multiple regression correlation: $\mathrm{r} 2=0.975$ ).

Table 4 presents the resulting regression equations for stature estimation in female subjects. In women, MLU was the most appropriate variable for stature estimation $(\mathrm{r} 2=0.888)$. In the equation derived from stepwise regression analysis using partial segments, MLU and VDHH were selected for female subjects (multiple regression correlation: $\mathrm{r} 2=0.950$ ).

Table 5 presents the resulting regression equations for stature estimation using data for both male and female subjects. In this combined sample, MLU was the most appropriate variable to estimate stature $(\mathrm{r} 2=0.906)$. In the equation derived from stepwise regression analysis using partial segments, 3 variables-MLU, MLH and TDHH-were selected for men (multiple regression correlation: $\mathrm{r} 2=0.949)$.

On comparing coefficients of determination, $\mathrm{r} 2$ values from simple regression analysis were found to be smaller than those derived from multiple regression analysis (Tables 3-5).

\section{DISCUSSIONS}

This investigation was performed for a sample from the Korean population in which it was possible to measure height directly. The regression formulae and tables were derived from calculated heights.

Some studies showed that long bones are the most appropriate specimens for evaluating stature (4). Other studies demonstrated that lower limb bones are better predictors of stature than upper limb bones $(1,16,27)$. However, to estimate stature from lower limb bones were already reported on Korean population (28) and the lower limb bones may not be found at the scene. Therefore, upper limb bones were evaluated in this study. Moreover, partial measurements of humerus were measured in this study because partial segments of humerus may be found at the scene.

Hauser et al. (7) and Prasad et al. (29) reported that the length of the femur was closely correlated with stature, but another report (4) found the ulna and radius to be one of the important materials for estimating stature. Although MLU was a slightly better predictor of stature than MLH and MLR in both sexes in the Korean population, the main predictors of stature differ between populations (Table 6). Additionally, the Korean population-according to the results of Choi et al. (25) and the present study-were existed the difference the correlation to estimate stature of each other (Table 6). These results support the observation that, anthropometric dimensions vary with populations, and that these variations are attributed to genetic and environmental factors. 
Among Asian populations, Korean was slightly better predictors than Thai and Japanese for both sexes (Table 6). From these results, it is clear that regression formulae need to be determined for the Korean population

One study investigated the correlation between postmortem stature and the dried limb bone lengths of adult Korean men (25). The present study revealed a slightly higher correlation of limb bone lengths with stature than that obtained by Choi et al. (25). These differences between 2 Korean studies may reflect secular change between the study samples. In addition, Choi et al. (25) insisted that the regression equations for stature estimation in women were needed because no regression equations had been developed for female subjects. For this reason, the regression equations in the present study are invaluable.

Forensic anthropologists are often confronted with fragmentary remains (29). Steele and McKern (30) reported equations for assessing stature from fragmented long bones. The results of the present study have demonstrated that variables such as EBH correlate better with stature than other partial measurements (Tables 3-5). These results indicate that the variable related to the epicondylar breadth in case of humerus, the easier it is to estimate stature even if the bone was found in fragmented condition.

Some studies (12) have investigated the difference between living and postmortem statures. Jantz et al. (8) indicated that the principal difficulty in developing stature estimation formulae was the lack of reliable antemortem height estimates. All previous studies have shown that the living stature is $2-3 \mathrm{~cm}$ shorter than the reported antemortem stature. A few studies have indicated that dry bones are shorter than fresh bones by approximately $2 \mathrm{~mm}(7,10)$. The estimated values in this study obtained through the application of these methods are estimations of cadaveric height and not living stature. The limitation of this study was the inability to measure antemortem stature. However, we attempted to measure the stature at 3-5 days after death.

In this study, long bones (humerus, ulna and radius) were used for estimating stature, and no other study has estimated stature from long bones in fragmented condition in Korean subjects, thus allowing more accurate stature estimation and improving the process of identification of missing persons.

\section{ACKNOWLEDGEMENTS}

This research was supported by basic science research program through the national research foundation of Korea (NRF) funded by the Ministry of Education, Science and Technology (NO. 2014R1A1A1006195)

\section{REFERENCES}

[1] Didia BC, Nduka EC, Adele O. Stature estimation formulae for Nigerians. J Forensic Sci. 2009;54:20-21.

[2] Telkka A. On the prediction of human stature from the long bones. Acta Anat. 1950;9:103117. 
[3] Angel A, Cisneros HB. Technical note: modification of regerssion equations used to estimate stature in Mesoamerican skeletal remains. Am J Phys Anthropol. 2004;125:264265.

[4] Celbis $O$, Agritmis H. Estimation of stature and determination of sex from radial and ulnar bone lengths in a Turkish corpse sample. Forensic Sci Int. 2006;158:135-139.

[5] El-meligy MMS, Abdel-hady RH, Abdel-maaboud RM, Mohamed ZT. Estimation of human body built in Egyptians. Forensic Sci Int. 2006;159:27-31.

[6] Giannecchini M, Moggi-cecchi J. Stature in archeological samples from central Italy: methodological issues and diachronic changes. Am J Phys Anthropol. 2008; 135: 284-292.

[7] Hauser R, Smolinski J, Gos T. The estimation of stature on the basis of measurements of the femur. Forensic Sci Int. 2005;147:185-190.

[8] Jantz RL, Kimmerle EH, Baraybar JP. Sexing and stature estimation criteria for Balkan populations. J Forensic Sci. 2008;53:601-605.

[9] Kate BR, Mujumdar RD. Stature estimation from femur and humerus by regression and autometry. Acta Anat. 1976;94:311-320.

[10] Mendonca MCD. Estimation of Height from the Length of Long Bones in a Portuguese Adult Population. Am J Phys Anthropol. 2000;112:39-48.

[11] Mohanty NK. Prediction of height from percutaneous tibial length amongst Oriya population. Forensic Sci Int. 1998;98:137-141.

[12] Radoinova D, Tenekedjiev K, Yordanov Y. Stature estimation from long bone lengths in Bulgarians. Homo. 2002;52:221-232.

[13] Raxter MH, Ruff CB, Azab A, Erfan M, Soliman, El-sawaf A. Stature estimation in ancient Egyptians: a new technique based on anatomical reconstruction of stature estimation of stature from body parts. Am J Phys Anthropol. 2008;136:147-155.

[14] Sarajlic N, Cihlarz Z. Diverse stature estimation formulae applied to a Bosnian population. Bosnian J of Basic Med Sci. 2007;7:136-139.

[15] Trotter M, Gleser G. Estimation of stature from long bones of american whites and negroes. Am J Phys Anthropol.1952;10:463-514.

[16] Vercellotti G, Agnew AM, Justus HM, Sciulli PW. Stature estimation in an early medieval (XI-XII c.) Polish population: testing the accuracy of regression equations in a bioarcheological sample. Am J Phys Anthropol. 2009;140:135-142.

[17] Shahar S, Pooy NS. Predictive equations for estimation of stature in Malaysian elderly people. Asia Pacific J Clin Nutr. 2003;12:80-84.

[18] Kimura K. Estimation of stature from second metacarpal length in Japanese children. Ann Hum Biol. 1992;19:267-275.

[19] Knous BL, Arisawa M. Estimation of height in elderly Japanese using region-specific knee height equations. Am J Hum Biol. 2002;14:300-307.

[20] Hasegawa I, Kazuhiro U, Fukunaga T, Kimura R, Osawa M. Stature estimation formulae from radiographically determined limb bone length in a modern Japanese population. Legal Med. 2009; 11:260-266.

[21] Fan T, Chen XG, Zhou XR, Zhang ZH, Deng ZH, Wang HX. Stature estimation from length of tibias and fibulas measured in computed radiography of living body. Fa Yi Xue Za Zhi. 2008;24:118-121.

[22] Zheng T, Huang Y, Zhang JB, Zhao H, Wang YZ, Shu YK, Deng ZH. Stature estimation of teenagers by limb long bones with computerized radiography. Fa Yi Xue Za Zhi. 2011;27:178-181. 
[23] Auyeung TW, Lee JSW, Kwok T, Leung J, Leung PC, Woo J. Estimation of stature by measuring fibula and ulna bone length in 2443 older adults. J Nutr Health Aging. 2009;13:931-936.

[24] Mahakkanukrauh P, Khanpetch P, Prasitwattanseree S, Vichairat K, Case DT. Stature estimation from long bone lengths in a Thai population. Forensic Sci Int. 2011;210:279.e1-279.e7.

[25] Choi BY, Chae YM, Chung IH, Kang HS. Correlation between the postmortem stature and the dried limb-bone lengths of Korean adult males. Yonsei Med J. 1997;38:79-85.

[26] Shin DH, Oh CS, Kim YS, Hwang YI. Ancient-to-modern secular changes in Korean stature. Am J Phys Anthropol. 2012;147:433-442.

[27] Formicola V, Franceschi $M$. Regression equations for estimating stature from long bones of early holocene European samples. Am J Phys Anthropol. 1996;100: 83-88.

[28] Lee JH, Kim YS, Lee UY, Park DK, Jeong YG, Lee NS, Han SY, Han SH. Stature estimation from partial measurements and maximum length of lower limb bones in Koreans. Australian J Forensic Sciences. 2014;46:330-338.

[29] Prasad R, Vettivel S, Jeyaseelan L, Isaac B, Chandi G. Reconstruction offemur length from markers of its proximal end. Clin Anat. 1996;9:28-33.

[30] Steele DG, McKern TW. A method for assessment of maximum long bone length and living stature from fragmentary long bones. Am J Phys Anthropol. 1996;31:215-227.

\section{TABLES}

Table 1: Definitions related to measurements of femur, tibia and fibula

\begin{tabular}{ll}
\hline Variable & \multicolumn{1}{c}{ Definition } \\
\hline MLH & Maximum length of the humerus \\
MLU & Maximum length of the ulna \\
MLR & Maximum length of the radius \\
VDHH & Vertical diameter of the humeral head \\
TDHH & Transverse diameter of the humeral head \\
MDHH & Maximum diameter of the humeral head \\
EBH & Epicondylar breadth of the humerus \\
\hline
\end{tabular}

Table 2: Means and standard deviations (SD) of measured variables (mm)

\begin{tabular}{|c|c|c|}
\hline \multirow{2}{*}{ Variable } & Male & Female \\
\hline & Mean (SD) & Mean (SD) \\
\hline MLH & $304.6 \quad(13.8)$ & $283.6 \quad(10.5)$ \\
\hline MLU & $244.1 \quad(33.1)$ & $228.2 \quad(8.5)$ \\
\hline MLR & $224.9 \quad(30.8)$ & $209.2 \quad(8.8)$ \\
\hline VDHH & $46.4 \quad(2.5)$ & $41.1 \quad(2.1)$ \\
\hline TDHH & $43.1 \quad(2.2)$ & $38.3 \quad(2.3)$ \\
\hline
\end{tabular}




\begin{tabular}{lllll}
$\mathrm{MDHH}$ & 47.0 & $(2.5)$ & 41.4 & $(2.5)$ \\
$\mathrm{EBH}$ & 62.8 & $(3.4)$ & 55.4 & $(2.9)$ \\
\hline
\end{tabular}

Table 3: Regression equations for estimating stature in men (mm)

\begin{tabular}{|c|c|c|c|c|}
\hline Variable & Regression equations & & $\mathrm{R}^{2}$ & Sig. \\
\hline MLH & $5.061 * \mathrm{MLH}+133.449$ & $=$ Stature \pm 29.1 & 0.887 & 0.000 \\
\hline MLU & $6.285^{*} \mathrm{MLU}+113.027$ & $=$ Stature \pm 30.0 & 0.899 & 0.000 \\
\hline MLR & $6.809 *$ MLR +111.025 & $=$ Stature \pm 29.3 & 0.898 & 0.000 \\
\hline VDHH & $32.166 * \mathrm{VDHH}+180.979$ & $=$ Stature \pm 20.1 & 0.849 & 0.000 \\
\hline TDHH & $35.513 * \mathrm{TDHH}+145.690$ & $=$ Stature \pm 22.7 & 0.877 & 0.000 \\
\hline $\mathrm{MDHH}$ & $31.612 * \mathrm{MDHH}+189.445$ & $=$ Stature \pm 19.5 & 0.840 & 0.000 \\
\hline $\mathrm{EBH}$ & $24.209 * \mathrm{EBH}+157.635$ & $=$ Stature \pm 22.5 & 0.878 & 0.000 \\
\hline Stepwise & $\begin{array}{l}(2.902 * \mathrm{MLU})+(3.832 * \\
\mathrm{TDHH})+ \\
\mathrm{MLH})+31.629\end{array}$ & $=$ Stature & 0.975 & 0.000 \\
\hline
\end{tabular}

Table 4: Regression equations for estimating stature in women (mm)

\begin{tabular}{lllll}
\hline Variable & Regression equations & & $\mathrm{R}^{2}$ & Sig. \\
\hline MLH & $5.150 * \mathrm{MLH}+92.120$ & $=$ Stature \pm 26.0 & 0.880 & 0.000 \\
MLU & $6.429 * \mathrm{MLU}+85.179$ & $=$ Stature \pm 26.1 & 0.888 & 0.000 \\
MLR & $6.920 * \mathrm{MLR}+102.816$ & $=$ Stature \pm 25.0 & 0.880 & 0.000 \\
VDHH & $32.656 * \mathrm{VDHH}+204.791$ & $=$ Stature \pm 19.9 & 0.828 & 0.000 \\
TDHH & $34.775 * \mathrm{TDHH}+215.528$ & $=$ Stature \pm 16.9 & 0.809 & 0.000 \\
MDHH & $32.625 * \mathrm{MDHH}+197.096$ & $=$ Stature \pm 18.1 & 0.830 & 0.000 \\
EBH & $25.250 * \mathrm{EBH}+145.999$ & $=$ Stature \pm 21.8 & 0.868 & 0.001 \\
\hline Stepwise & $(5.193 * \mathrm{MLU})+(8.746 * \mathrm{VDHH})+8.004$ & $=$ Stature & 0.950 & 0.000 \\
\hline
\end{tabular}

Table 5: Regression equations for estimating stature in a mixed-gender sample ( $\mathrm{mm})$

\begin{tabular}{lllll}
\hline Variable & Regression equations & & $\mathrm{R}^{2}$ & Sig. \\
\hline MLH & $5.184^{*} \mathrm{MLH}+90.408$ & $=$ Stature \pm 41.0 & 0.896 & 0.000 \\
MLU & $6.308^{*} \mathrm{MLU}+109.652$ & $=$ Stature \pm 42.7 & 0.906 & 0.000 \\
MLR & $6.788^{*} \mathrm{MLR}+133.363$ & $=$ Stature \pm 40.9 & 0.901 & 0.000 \\
VDHH & $30.766^{*} \mathrm{VDHH}+262.673$ & $=$ Stature \pm 27.7 & 0.845 & 0.000 \\
TDHH & $33.632 * \mathrm{TDHH}+241.593$ & $=$ Stature \pm 28.6 & 0.853 & 0.000 \\
MDHH & $30.173 * \mathrm{MDHH}+275.938$ & $=$ Stature \pm 27.1 & 0.839 & 0.000
\end{tabular}




\begin{tabular}{lllll} 
EBH & $23.308^{*} \mathrm{EBH}+233.162$ & $=$ Stature \pm 31.8 & 0.874 & 0.000 \\
\hline Stepwise & $\begin{array}{l}\left(3.338^{*}\right. \\
\mathrm{TDHH})+\left(1.708^{*} \mathrm{MLH}\right)+48.889\end{array}$ & $=$ Stature & 0.949 & 0.000 \\
\hline
\end{tabular}

Table 6: Correlation $\left(\mathrm{r}^{2}\right)$ with other studies

\begin{tabular}{|c|c|c|c|}
\hline & MLH & MLU & MLR \\
\hline Male & & $r\left(r^{2}\right)$ & \\
\hline Turkish (2006) & & $(0.383)$ & $(0.408)$ \\
\hline Bulgarian (2002) & 0.998 & & \\
\hline $\begin{array}{l}\text { American white } \\
(1952)\end{array}$ & 0.790 & 0.755 & 0.756 \\
\hline $\begin{array}{l}\text { American negro } \\
\text { (1952) }\end{array}$ & 0.716 & 0.712 & 0.713 \\
\hline European (1996) & 0.900 & & 0.910 \\
\hline Polish (2009) & $(0.744)$ & $(0.334)$ & \\
\hline Thai (2011) & 0.667 & 0.660 & 0.672 \\
\hline Korean (1997) & 0.720 & 0.710 & 0.720 \\
\hline Japanese (2009) & 0.685 & & \\
\hline Egyptian (2008) & 0.656 & & 0.649 \\
\hline This study (2015) & 0.887 & 0.899 & 0.898 \\
\hline Female & & $r\left(r^{2}\right)$ & \\
\hline Turkish (2006) & & $(0.584)$ & $(0.727)$ \\
\hline $\begin{array}{l}\text { American } \\
(1952)\end{array}$ & 0.802 & 0.759 & 0.789 \\
\hline $\begin{array}{l}\text { American negro } \\
(1952)\end{array}$ & 0.748 & 0.649 & 0.633 \\
\hline Bulgarian (2002) & 0.998 & & \\
\hline Japanese (2009) & 0.670 & & \\
\hline European (1996) & 0.870 & & 0.810 \\
\hline Polish (2009) & $(0.640)$ & $(0.495)$ & \\
\hline Egyptian (2008) & 0.806 & & 0.580 \\
\hline Thai (2011) & 0.552 & 0.567 & 0.616 \\
\hline This study (2015) & 0.880 & 0.888 & 0.880 \\
\hline
\end{tabular}

